DOI: https://doi.org/10.32838/2523-4803/70-4-21

УДК 656.078

\title{
Кобилюх О.Я.
}

старший викладач кафедри маркетингу і логістики,

Національний університет «Львівська політехніка»

\section{Гірна О.Б.}

кандидат економічних наук, доцент,

Національний університет «Львівська політехніка»

Гасва Л.І.

кандидат хімічних наук, доцент,

Івано-Франківський національний технічний університет нафти і газу

\author{
Kobyliukh Oksana \\ National University Lviv Polytechnic \\ Hirna Olha \\ National University Lviv Polytechnic
}

Hayeva Lyubov

Ivano-Frankivsk National Technical University of Oil and Gas

\section{КЛЮЧОВІ АСПЕКТИ ТРАНСПОРТНОЇ ЛОГІСТИКИ В УМОВАХ ПАНДЕМІї COVID-19}

У статті проаналізовано основні тенденції на ринку транспортної логістики до появи пандемії короновірусу та в процесі ї̈ виникнення. Особливий акиент зроблено на динаміку вантажообігу та перевезення вантажів по Украӥні за видами транспорту за останні періоди. Окреслено обсяги перевезених вантажів за видами транспорту, причому досліджено основні тендениії у перші два місяці розвитку пандемії. Розкрито сутність ключових елементів рекомендацій СС зі сприяння безпереикодному руху вантажів, доступності товарів та послуг у межах TEN-T. Наведено низку викликів для транспортної логістики в умовах COVID-19 з урахуванням характерних особливостей вітчизняного ринку, на основі яких розроблено низку пропозицій стосовно адаптації підприємств транспортної логістики до швидкоплинних умов сучасного ринку.

Ключові слова: транспортна логістика, пандемія COVID-19, аутсорсинг, “збірні вантажі”, мобільні перевізники, IT-технологї.

Постановка проблеми. В останній час перспективно та швидкими темпами відбувається розвиток одного із сегментів ринку логістичних послуг - сфери вантажних перевезень та пов'язаної з нею транспортної експедиції. Зростаючі вимоги вантажовласників, високий рівень конкуренції у галузі та взаємини із зовнішнім середовищем вимагають від підприємств транспортної галузі пошуку нових шляхів розвитку, пошуку і використання нових підходів та інструментів до залучення та утримання своїх замовників. Потреба у розвитку ринку транспортно-експедиційних послуг очевидна. Не тільки рівень витрат, але й якість пропонованих послуг, у тому числі і базових, не відповідає поточним потребам підприємств та завданням розвитку країни.

Серйозні зміни внесла у діяльність транспортноекспедиційних компаній пандемія короновірусу, порушивши при цьому стандартні відносини між виробниками і споживачами. Закриття кордонів між країнами та введення режиму самоізоляції спричинило значне скорочення виробничих потужностей. Тобто пройшла істотна зміна ситуації як на місцевих, так і на глобальних ринках. Запровадження карантинних заходів вплинуло на діяльність транспортних компаній, зокрема, крім обмеження руху вантажного транспорту, відбулося скорочення клієнтів цього сегменту ринку. Загалом експерти прогнозують скорочення вантажоперевезень на європейському ринку мінімум на 40\% [4]. Окреслені вище тенденції і зумовили тематику цього дослідження.

Аналіз останніх досліджень та публікацій. Питання формування та ефективності функціонування потенціалу транспортної логістики досліджу-ються такими вченими, як Б. Анікін, Д. Бауерсокс, А. Гаджинський, О. Глогусь, Є. Голіков, А. Кальченко, Д. Клос, Є. Крикавський, Е. Мате, Л. Міротін, Ю. Неруш, В. Ніколайчук, М. Окландер, Перебийніс В.І., Ю. Пономарьова, О. Семененко, В. Сергеєв, І. Смирнов, В. Стаханов, І. Ташбаєв, Д. Тіскьє, В. Українцев, Н. Чухрай та ін. [1]. Аналіз результатів їхніх досліджень засвідчує про доцільність дослідження цієї тематики не тільки у розрізі звичних для нас умов, а й у період розвитку пандемії COVID-19. 
Формулювання цілей статті. Мета дослідження визначається як фор-мування елементів розвитку транспортно-експедиційних підприємств в умовах пандемії COVID-19, яка базуються на основі поєднання попереднього аналізу ринку транспортних послуг з умовами сьогодення.

Виклад основного матеріалу. Сучасні умови ринку вантажних перевезень характеризуються підвищенням конкуренції, зменшенням прибутку, підвищенням та появою нових вимог до якості послуг, що надаються. Умови ринку стають дедалі жорсткішими для логістичних та транспортно-експедиційних компаній. Особливо це стосується автомобільних вантажоперевізників.

Нині автомобільна транспортна система України нараховує понад 9,1 млн одиниць транспорту, в тому числі до 1,3 млн вантажних автомобілів та до 850 тис. одиниць мототранспорту.

На українському ринку комерційних перевезень нині загалом здійснює діяльність до 56,3 тис. перевізників, у використанні яких - понад 154 тис. одиниць вантажних транспортних засобів.

За даними офіційної статистики, на ринку вантажних перевезень за 2019 р. вантажообіг усіх видів транспорту становив 338,9 млрд. т км, що проти такого ж періоду 2018 р. становить 102,1\% від обсягу вантажообігу (табл. 1). Останніми роками зростання частки імпортних товарів на ринку України, збільшення обсягів торгівлі через Інтернет перекрили зменшення внутрішніх перевезень вітчизняних товарів і забезпечили рівень вантажних перевезень.

Підприємствами транспорту у 2019 р. перевезено майже 675 млн т вантажів, що становить 108\% від обсягу перевезень у 2018 р. Протягом 2019 р. залізничним транспортом перевезено у внутрішньому сполученні й на експорт майже 313 млн т вантажів, що на 2,9\% менше, ніж у 2018 р. За даними офіційної статистики, частка вантажних перевезень автомобільним транспортом становить майже $36 \%$. У січні-квітні 2020 р. вантажообіг підприємств транспорту становив 90,6 млрд т км, або 81,8\% від обсягу січня-квітня 2019 р. (табл. 2).

Загалом підприємствами транспорту у січні-квітні 2020 р. перевезено 184,8 млн т вантажів, що становить 84,7\% від обсягів січня-квітня 2019 р. За період січняквітня 2020 р. кількість вантажів за рахунок перевезень автомобільним транспортом становить 57,6 млн т км, і це становить 79,8\% до відповідного періоду 2019 р.

Таблиця 1

Динаміка вантажообігу та перевезення вантажів по Україні

за 2019 р. та січень-квітень 2020 р. за видами транспорту

\begin{tabular}{|c|c|c|c|c|c|c|}
\hline \multirow{3}{*}{ Вид транспорту } & \multicolumn{3}{|c|}{ Вантажообіг } & \multicolumn{3}{|c|}{ Кількість вантажу } \\
\hline & \multicolumn{2}{|c|}{ млН т км } & \multirow{2}{*}{$\begin{array}{c}2019 \text { y \% } \\
\text { до } 2018\end{array}$} & \multicolumn{2}{|c|}{ млн Т } & \multirow{2}{*}{$\begin{array}{r}2019 \text { y \% } \\
\text { до } 2018\end{array}$} \\
\hline & 2019 & $\begin{array}{c}\text { Січень- } \\
\text { квітень } 2020\end{array}$ & & 2019 & $\begin{array}{c}\text { Січень- } \\
\text { квітень } 2020\end{array}$ & \\
\hline $\begin{array}{l}\text { Транспорт загалом, } \\
\text { у тому числі: }\end{array}$ & 338885,2 & 90606,0 & 102,1 & 674,5 & 184,8 & 108,0 \\
\hline - залізничний & 181844,7 & 56822,8 & 97,6 & 312,9 & 96,8 & 97,1 \\
\hline - автомобільний & 48831,5 & 13520,1 & 114,7 & 242,7 & 57,6 & 129,7 \\
\hline - водний & 3386,9 & 840,7 & 100,7 & 6,1 & 1,3 & 109,2 \\
\hline - трубопровідний & 104528,1 & 19340,2 & 105,3 & 112,7 & 29,1 & 103,0 \\
\hline - авіаційний & 294,0 & 82,2 & 86,6 & 0,1 & 0,02 & 92,7 \\
\hline
\end{tabular}

Джерело: власне опрачювання на основі [5]

Таблиця 2

Обсяги перевезених вантажів за видами транспорту за 2020 р.

\begin{tabular}{|c|c|c|c|c|c|}
\hline Вид транспорту & Одиниці виміру & Січень & $\begin{array}{l}\text { Січень- } \\
\text { лютий }\end{array}$ & $\begin{array}{c}\text { Січень- } \\
\text { березень }\end{array}$ & $\begin{array}{l}\text { Січень- } \\
\text { квітень }\end{array}$ \\
\hline \multirow{2}{*}{ Транспорт загалом, у т. ч. } & Млн т & 44,0 & 90,1 & 140,7 & 184,8 \\
\hline & у \% до відповідного періоду 2019 р. & 87,7 & 89,3 & 86,9 & 84,7 \\
\hline \multirow{2}{*}{ - залізничний } & Млн т & 23,9 & 47,3 & 73,9 & 96,8 \\
\hline & у \% до відповідного періоду 2019 р. & 97,4 & 97,4 & 95,9 & 92,5 \\
\hline \multirow{2}{*}{ - автомобільний } & Млн т & 13,2 & 28,2 & 43,7 & 57,6 \\
\hline & у \% до відповідного періоду 2019 р. & 92,6 & 90,3 & 82,1 & 79,8 \\
\hline \multirow{2}{*}{ - водний } & Млн т & 0,2 & 0,5 & 0,9 & 1,3 \\
\hline & у \% до відповідного періоду 2019 р. & 116,8 & 113,1 & 87,4 & 97,1 \\
\hline \multirow{2}{*}{ - трубопровідний } & мЛнТ & 6,7 & 14,1 & 22,2 & 29,1 \\
\hline & у \% до відповідного періоду 2019 р. & 59,8 & 68,4 & 72,4 & 72,7 \\
\hline \multirow{2}{*}{ - авіаційний } & Млн т & 0,01 & 0,01 & 0,02 & 0,02 \\
\hline & у \% до відповідного періоду 2019 р. & 90,3 & 88,7 & 86,4 & 90,7 \\
\hline
\end{tabular}

Джерело: власне опрацювання на основі [5] 
Окремим викликом для транспортної галузі став карантин, який було введено у березні 2020 р. у зв'язку iз захворюванням на COVID-19.

В умовах пандемії COVID-19 серед основних тенденцій в Євросоюзі можна виокремити: 1) зниження обсягу внутрішніх та міжнародних перевезень; 2) зменшення кількості автотранспорту на дорогах через режим самоізоляції; 3) відсутність обмежень стосовно руху вантажного транспорту у вихідні дні; 4) зниження ставки на тарифні перевезення всередині Свропи [8].

ЄC виробив рекомендації для сприяння безперешкодному руху вантажів, доступності товарів та основних послуг у рамках Транс'європейської опорної транспортної мережі (TEN-T), до якої включена Україна. Рекомендації мають сприяти тим, хто, наражаючи себе на небезпеку, з міста в місто, з країни в країну доставляє потрібні людям речі: продукти, засоби особистого захисту, ліки та будь які інші товари. Так, зокрема, у рекомендаціях зазначається [2]:

1) оформлення водіїв вантажних транспортних засобів для перетину кордонів на автомобільних дорогах транс'європейських дорожніх мереж, включаючи час на будь-які перевірки та обстеження стану здоров'я, має тривати не більше 15 хвилин;

2) під час митного оформлення водії можуть не залишати кабін своїх вантажівок, у тому числі під час заповнення форм і бланків, а отримання, перевірка та повернення паперових документів працівниками національного контролю має здійснюватися 3 дотриманням мінімальної безпечної відстані;

3) час очікування та надання змоги безперешкодного пересування має бути забезпечено представникам всіх компаній-перевізників: водіям, пілотам, машиністам, а також членам їхніх екіпажів, за умови, що жоден 3 них не має симптомів захворювання.

Пандемія COVID-19 істотно вплинула на логістичну сферу і в Україні. Через серйозну зупинку морських, автомобільних та авіаційних перевезень суттєві проблеми із транспортуванням відчули багато галузей промисловості.

Виходячи із вище сказаного, виникає нагальна потреба у виокремленні пріоритетних напрямів розвитку транспортно-експедиційних підприємств в умовах пандемії (рис. 1). Детальніше розглянемо основні із них.

Посилення боротьби за клієнта сприяє виникненню цінового демпінгу на ринку вантажоперевезень, оскільки кількість вантажів зменшується, а багато транспорту залишається не залученим у процеси транспортування, при цьому більшість компаній не спроможні витримати тривалий демпінговий процес.

Пандемія COVID-19 сприяє виходу із логістичного ринку слабких гравців, тобто це «ідеальний шторм». Ринок найближчим часом покинуть дрібні і деякі середні гравці, при цьому відбудеться низка банкрутств, поглинань, злиттів. 3 іншого боку, логістичні компанії, позиції яких є стійкими на ринку, матимуть можливість розширити свою частку ринку.

Для посилення своїх конкурентних позицій на ринку транспортні логістичні компанії почнуть об'єднуватися в communities для спільного користування послугами одна одної, іншими словами, колаборуватися, що дозволить розробляти унікальні пропозиції для клієнтів.

Зростання курсу валют та пандемія спричинили відмову від оновлення автопарку у 90\% логістичних компаній [6]. Це відповідно спричинило зростання попиту на послуги, пов'язані із ремонтом та технічним обслуговуванням автопарків.

В останній час динамічно розвивається тенденція збільшення попиту на послугу «збірні вантажі». Спостерігається тренд до зменшення обсягів партій вантажів, які перевозяться, на противагу чому відбувається збільшення кількості відправлень «збірних вантажів». Саме розвиток аутсорсингу буде поштовхом для гравців ринку «заповнювати» транспортні засоби та групувати партії замовлення на взаємовигідних умовах.

Питання оптимізації і діджіталізації в логістиці стоїть давно, але мало хто наважувався на реальні та докорінні зміни. Пандемія COVID-19 змусила більшість логістичних компаній активно впроваджувати у діяльність новітні IT-технології. Доцільно зауважити, що відбувається активне використання IT-платформ у логістичних компаніях 3 метою обміну тарифами i ставками [6].

Новим трендом в транспортній логістиці на найближче майбутнє стане замовлення перевезень із мобільного пристрою, тобто поява окремої галузі «мобільні перевізники». Це зумовлено тим, що власники вантажу дедалі частіше орієнтуються на повний спектр послуг із режимом доступу зі свого мобільного пристрою. Клієнт отримує можливість замовити перевезення на цифровій логістичній платформі, натискаючи на кнопку в мобільному додатку, зокрема, відправка посилок за номером телефону: функція доступна для всіх користувачів мобільного додатка логістичного оператора.

У зв'язку із закриттям кордонів через пандемію змінилися напрями розвитку вантажних перевезень, а саме відбулося зменшення вантажних потоків 3 країн Азії, Китаю, що відповідно привело до розвитку виробництва всередині країни та розвитку внутрішніх продуктів. Цей тренд сприятиме розвитку внутрішньої логістики та вихід іiї на новий рівень якості.

Не тільки можливості збереження бюджету, а й істотній економії часу сприятиме активне впровадження у сферу транспортної логістики процесів аутсорсингу, тобто відбувається актуалізація передачі непрофільних процесів та послуг на аутсорсинг.

Одним із головних трендів сучасності стає безконтактна кур'єрська доставка. Кінцевому споживачу пропонується найширший асортимент товарів із безконтактною доставкою додому. 3 метою уникнення громадських місць в умовах пандемії, покупці готові переплачувати 5-10\% від вартості за товари зі швидкою доставкою (1-3 дні) [4].

Продовженням ідеї безконтактної кур'єрської доставки вантажів є розвиток доставки посилок за допо- 


\section{Виклики пандемії COVID-19 для транспортної логістики}

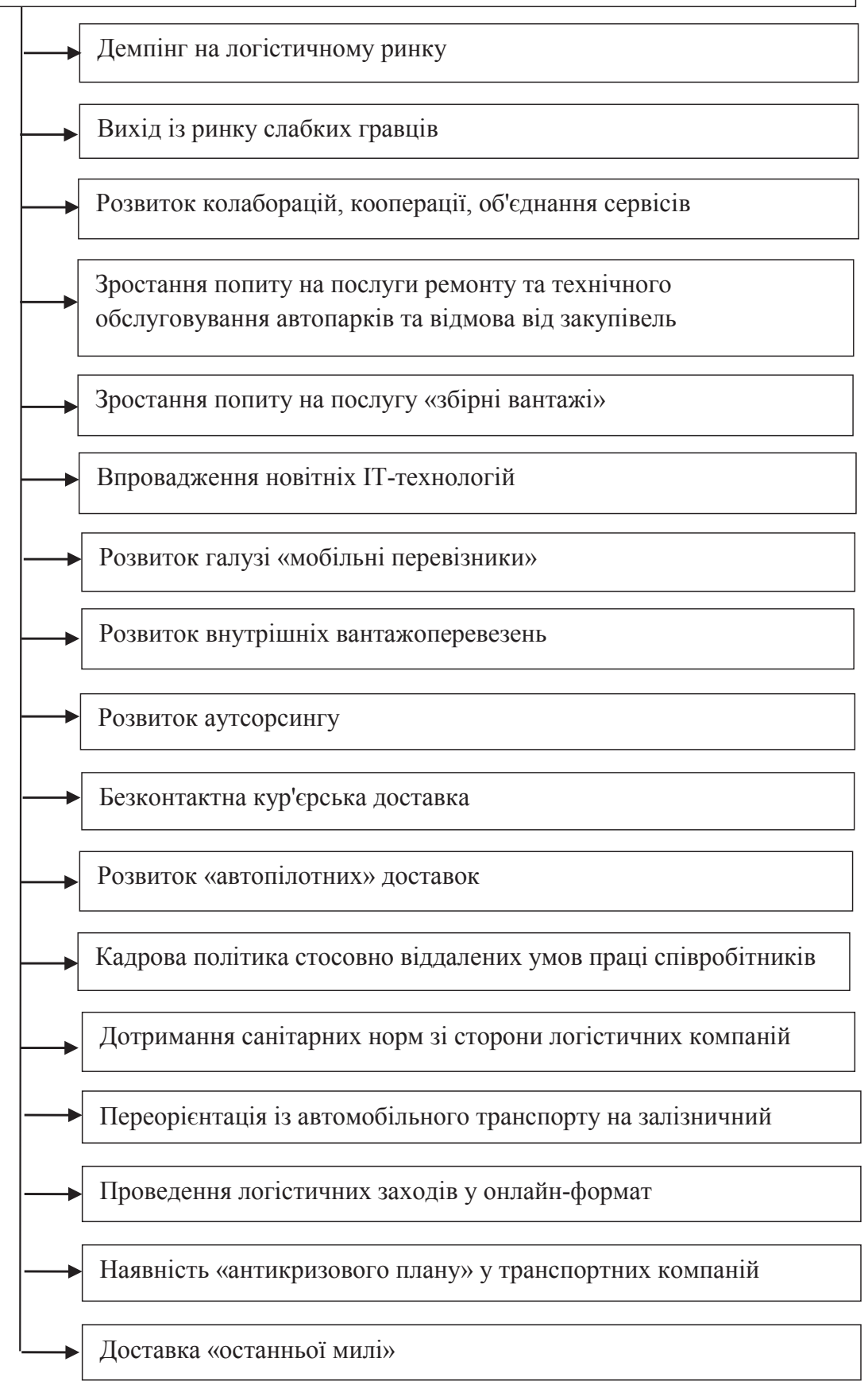

Рис. 1. Виклики пандемії COVID-19 для транспортної логістики

Джерело: власне опрацювання на основі [6, 7]

могою «дронів» або «автопілотної» доставки. Широкої популярності вона набула в Китаї в умовах пандемії.

Відбуваються істотні зміни у кадровій політиці багатьох логістичних компаній, вони переводять своїх працівників на віддалену форму праці, що вимагає оптимізації та автоматизації всіх бізнес-процесів у логістичній компанії.

3 метою безпеки транспортно-експедиційні компанії будуть змушені дотримуватися санітарних норм, проводити дезінфекцію обладнання, транспортних засобів, адже ці умови їм диктуватиме користувач їхніх послуг.

Незважаючи на те, що кордони відкриті для міжнародних вантажних відправлень, строгі перевірки, карантин, заміна водіїв і інші заходи можуть уповільнювати швидкість доставки автомобільним транспортом, що відкриває нові перспективи для залізничних перевезень, тобто несподіваним трендом стала переорієнтація підприємств із автотранспорту на залізничний. При цьому скасування пасажирських перевезень 
дозволило звільнити розклад для курсування вантажних потягів.

Безсумнівним трендом стає перехід усіх світових логістичних заходів у онлайн-формат. Тренд на проведення більшості заходів у логістичній сфері в онлайнформаті збережеться, тому що цей формат проведення зустрічей, переговорів, вебінарів, конференцій показав високу ефективність. Згідно із дослідженнями, більше $60 \%$ запланованих заходів у 2020 р. без онлайн-формату приречені на фіаско.

Для транспортних компаній обов'язковою стає наявність «антикризового плану». Досвід кризи в період пандемії змушує керівництво логістичних компаній мати в запасі «план В - пакет антикризових заходів» із фінансовим підгрунтям.

Особливо важливою умовою за цих обставин стає доставка «останньої милі». Кризу порівняно легко перенесуть компанії, які здійснюють автомобільні доставки, й оператори, що працюють на «останній милі». Подолати кризу найлегше буде компаніям без основних засобів, тобто експедиторам. Додаткове фінансове навантаження (транспортне обладнання, яке закуповується в основному в лізинг) зараз може тільки погіршити ситуацію.

Висновки. Поліпшення сервісу, збільшення швидкості поставки, професіоналізація логістичних послуг стають необхідними чинниками, які допоможуть подолати стагнацію бізнесу. Подолати спад на ринку транспортних перевезень та залишитися конкурентоспроможними зможуть лише ті компанії, що спроможуться вибудувати політику зменшення постійних і змінних витрат із найменшими втратами для бізнесу.

Таким чином, окреслені вище тенденції функціонування транспортно-експедиційних підприємств в умовах пандемії дозволять більшості із них пристосуватися до змінних умов зовнішнього середовища, зберігши при цьому високі конкурентні позиції на ринку, зменшивши рівні логістичних витрат та підвищивши якість обслуговування клієнтів через надання різного спектру необхідних послуг.

\section{Список літератури:}

1. Стельмащук А.М. Оцінка ефективності транспортно-логістичного потенціалу сільських територій / Міжнародний науково-виробничий журнал «Сталий розвиток економіки», 2015. Вип. 26. № 1. С. 42-50.

2. ЄС виробив рекомендації для сприяння безперешкодному руху вантажів, доступності товарів та послуг у рамках TEN-T,-Наталія Форсюк. URL: https://www.kmu.gov.ua/news/yes-virobiv-rekomendaciyi-dlya-spriyannya-bezpereshkodnomuruhu-vantazhiv-dostupnosti-tovariv-ta-poslug-u-ramkah-ten-t-nataliya-forsyuk (дата звернення: 29.06.2020).

3. Перспективи розвитку автомобільних перевезень в світі URL: https:/www.interfreight.biz/ua/pro-kompaniyu/ zhittya-kompaniji/344-perspektivi-rozvitku-avtomobilnikh-perevezen-v-sviti.html (дата звернення: 03.05.2020).

4. План порятунку: чи може Україна налагодити ефективну логістику. URL: https://mind.ua/publications/20179078plan-poryatunku-chi-mozhe-ukrayina -nalagoditi-efektivnu-logistiku (дата звернення: 21.05.2020).

5. Статистичні дані по галузі автомобільного транспорту. URL: https://mtu.gov.ua/content/statistichni-dani-po-galuziavtomobilnogo transportu.html (дата звернення: 09.05.2020).

6. Стратегія розвитку транспортної галузі України в умовах карантину: залізниця, порти та автотранспорт. URL: https://agropolit.com/spetsproekty/720-strategiya-rozvitku-transportnoyi-galuzi-ukrayini-v-umovah-karantinu-zaliznitsyaporti-ta-avtotransport (дата звернення: 28.05.2020).

7. Український транспорт i коронавірус: як впливає карантин на ключову галузь економіки. URL: https://www.radiosvoboda.org/a/30498066.html (дата звернення: 20.06.2020).

8. Швидше за все повезе, ось тільки на чому? Аналіз ринку вантажоперевезень в Україні. URL: https:/pro-consulting.ua/ua/ pressroom/skoree-vsego-povezet-vot-tolko-na-chem-analiz-rynka-gruzoperevozok-v-ukraine (дата звернення: 28.05.2020).

\section{References:}

1. Stelmashchuk A. (2015) Otsinka efektyvnosti transportno-lohistychnoho potentsialu sil's'kykh terytorij [Estimation of efficiency of rural territories transport and logistic potential]. Sustainable economic development, vol. 26(1), pp. 42-50. (in Ukrainian)

2. YeS vyrobyv rekomendatsii dlia spryiannia bezpereshkodnomu rukhu vantazhiv, dostupnosti tovariv ta posluh u ramkakh TEN-T, - Nataliia Forsiuk [The EU develops recommendations to ensure freight moving across the EU, continuous flow of goods and services within the TEN-T framework]. Available at: https://www.kmu.gov.ua/news/yes-virobiv-rekomendaciyi-dlya-spriyannya-bezpereshkodnomu-ruhu-vantazhiv-dostupnosti-tovariv-ta-poslug-u-ramkah-ten-t-nataliya-forsyuk (accessed 30.06.2020).

3. Perspektyvy rozvytku avtomobil'nykh perevezen'v sviti [Prospects for the development of road transport in the world]. Available at: https://www.interfreight.biz/ua/pro-kompaniyu/zhittya-kompaniji/344-perspektivi-rozvitku-avtomobilnikh-perevezen-v-sviti.html (accessed 03.05.2020).

4. Plan poriatunku: chy mozhe Ukraina nalahodyty efektyvnu lohistyku [Rescue plan: can Ukraine establish efficient logistics]. Available at: https://www.interfreight.biz/ua/pro-kompaniyu/zhittya-kompaniji/344-perspektivi-rozvitku-avtomobilnikh-perevezen-v-sviti.html (accessed 03.05.2020).

5. Statystychni dani po haluzi avtomobil'noho transportu [Road Transport Statistics]. Available at: https://mtu.gov.ua/ content/statistichni-dani-po-galuzi-avtomobilnogo transportu (accessed 09.05.2020). 
6. Stratehiia rozvytku transportnoi haluzi Ukrainy v umovakh karantynu: zaliznytsia, porty ta avtotransport [Strategy of Ukrainian transport industry in the conditions of quarantine: railway, ports and road transport]. Available at: https://agropolit.com/ spetsproekty/720-strategiya-rozvitku-transportnoyi-galuzi-ukrayini-v-umovah-karantinu-zaliznitsya-porti-ta-avtotransport (accessed 28.05.2020).

7. Ukrains'kyj transport i koronavirus: iak vplyvaie karantyn na kliuchovu haluz' ekonomiky [Ukrainian transport and coronavirus: how quarantine affects a key sector of the economy]. Available at: https://www.radiosvoboda.org/a/30498066.html (accessed 20.05.2020).

8. Shvydshe za vse poveze, os' til'ky na chomu? Analiz rynku vantazhoperevezen'v Ukraini [Surely ride, but on what? Analysis of the freight market in Ukraine]. Available at: https://pro-consulting.ua/ ua/pressroom/skoree-vsego-povezet-vottolko-na-chem-analiz-rynka-gruzoperevozok-v-ukraine (accessed 28.05.2020).

\section{КЛЮЧЕВЫЕ АСПЕКТЫ ТРАНСПОРТНОЙ ЛОГИСТИКИ В УСЛОВИЯХ ПАНДЕМИИ COVID-19}

В статье проанализированы основные тенденции на рынке транспортной логистики до появления пандемии короновирусу и в процессе ее возникновения. Особый акиент сделан на динамику грузооборота и перевозки грузов по Украине по видам транспорта за последние периоды. Определены объемы перевозимых грузов по видам транспорта, причем исследованы основные тенденции в первые два месяиа развития пандемии. Раскрыта сущность ключевых элементов рекомендаций ЕС по содействию беспрепятственному движению грузов, доступности товаров и услуг в рамках TEN-T. Представлен ряд вызовов для транспортной логистики в условиях COVID-19 с учетом характерных особенностей отечественного рынка, на основе которых разработано ряд предложений по адаптации предприятий транспортной логистики в скоротечных условиях современного рынка.

Ключевые слова: транспортная логистика, пандемия COVID-19, аутсорсинг, “сборные грузы”, мобильные перевозчики, IT-технологии.

\section{KEY ASPECTS OF TRANSPORT LOGISTICS DURING THE PANDEMIC COVID-19}

The priority position of transport logistics in the modern economy is revealed, namely the importance in forecasting not only delivery costs, but also in planning transport costs in general to fulfill the order of transport services consumers. Analysis and design of transport logistics activity of the enterprise involves taking into account such optimal requirements as type of transportation, type of transport, type and brand of rolling stock, operation of load carrying capacity vehicles, schemes of inventory, creation of infrastructure objects that necessary for service of a material flow, their rational spatial location, development of the transport network and routing of material flow. A comparative analysis of the main trends in the transport logistics market before the coronavirus COVID-19 pandemic and on the basis of studies of the dynamics of inventory turnover and freightage in terms of each mode of transport (rail, water, road, pipeline, aviation) and freight traffic in Ukraine in 2020. It is emphasized that the instability of the economic situation in the country has con-tributed to falling demand for transport services and the projected decline in the provision of transport services, which has forced most companies to reduce cost optimization and reduce staff. Some of them, especially unstable enterprises, closed their fleets and tried to "get out of the game» with minimal costs. It should also be noted a significant decrease in the volume of container traffic (including multimodal transport) during this period. The article focuses on the analysis of the challenges posed by the coronavirus COVID-19 pandemic: dumping in the logistics market; market exit of weak players; development of collaborations; growing demand for fleet repair and maintenance services, refusal to purchase; increase demand for the service "groupage cargo»; implementation of the latest IT-technologies; development of ant logistics; increasing the scale of domestic freight shiping; development of outsourcing; contactless delivery; development of self-drive vehicle; changing attitudes regarding remote working practicies; compliance with sanitary norms by logistics companies; reorientation from road to rail transport; translation of logistics activities into online; ability of an «anti-crisis plan» in transport companies; last mile delivery.

Key words: transport logistics, pandemic COVID-19, outsourcing, "groupage cargoes", ant logistics, IT-technologies. 